\title{
Microblade Technology in Quartz during the Mesolithic in Eastern Middle Sweden
}

\author{
Fredrik Molin \& Roger Wikell
}

\begin{abstract}
The authors present a material that has previously not been given much attention: microblades and microblade cores of quartz from eastern middle Sweden. The focus is on the technology, core types, geographical distribution and dating. The debate on how to interpret the quartz material of the region in cultural terms and the role of the microblade technology in this discussion, are also dealt with. During recent years, many excavations and special surveys have supplied the archaeologists in eastern middle Sweden with new source material. An increased knowledge of quartz is an important factor in the development of this field of research. The authors found it very helpful to discuss the newly found cores and blades and their technical execution with Kjel Knutsson of Uppsala University. Generally speaking, the Mesolithic quartz materials from eastern middle Sweden are dominated by two methods of reduction: freehand-platform and bipolar-on-anvil. The latter method regularly produces thin flakes that resemble microblades. In this article, however, focus will be on microblades sensu stricto. It seems that the production of quartz microblades is more common than previously thought. Early reports from sites such as Sjövreten and Skumparberget are no longer anomalies.
\end{abstract}

Fredrik Molin, National Heritage Board, Eastern Archaeological Excavations Division (UV Öst), Roxengatan 7, SE-582 73 Linköping, Sweden. Roger Wikell, Tyresta Forest Foundation, Tyresta by. SE-136 51 Handen, Sweden.

Key words: microblade, microblade core, quartz, Mesolithic, eastern middle Sweden

\section{MAINLAND AND ARCHIPELAGO CULTURE IN EASTERN MIDDLE SWEDEN}

A brief description of the region's geography during the Mesolithic is motivated. Eastern middle Sweden refers here to the provinces of Östergötland, Södermanland, Närke, Västmanland and Uppland.

During the entire postglacial period and up to the present day, the region has consisted of a coastal area with archipelagos in the east and a mainland area in the west. In the Mesolithic, large parts of the region were open water and archipelagos. Shore displacement has generally been regressive since deglaciation, with continuous changes in the distribution of land and water and an average eastward movement of the coastal zone (Åkerlund 1996). 


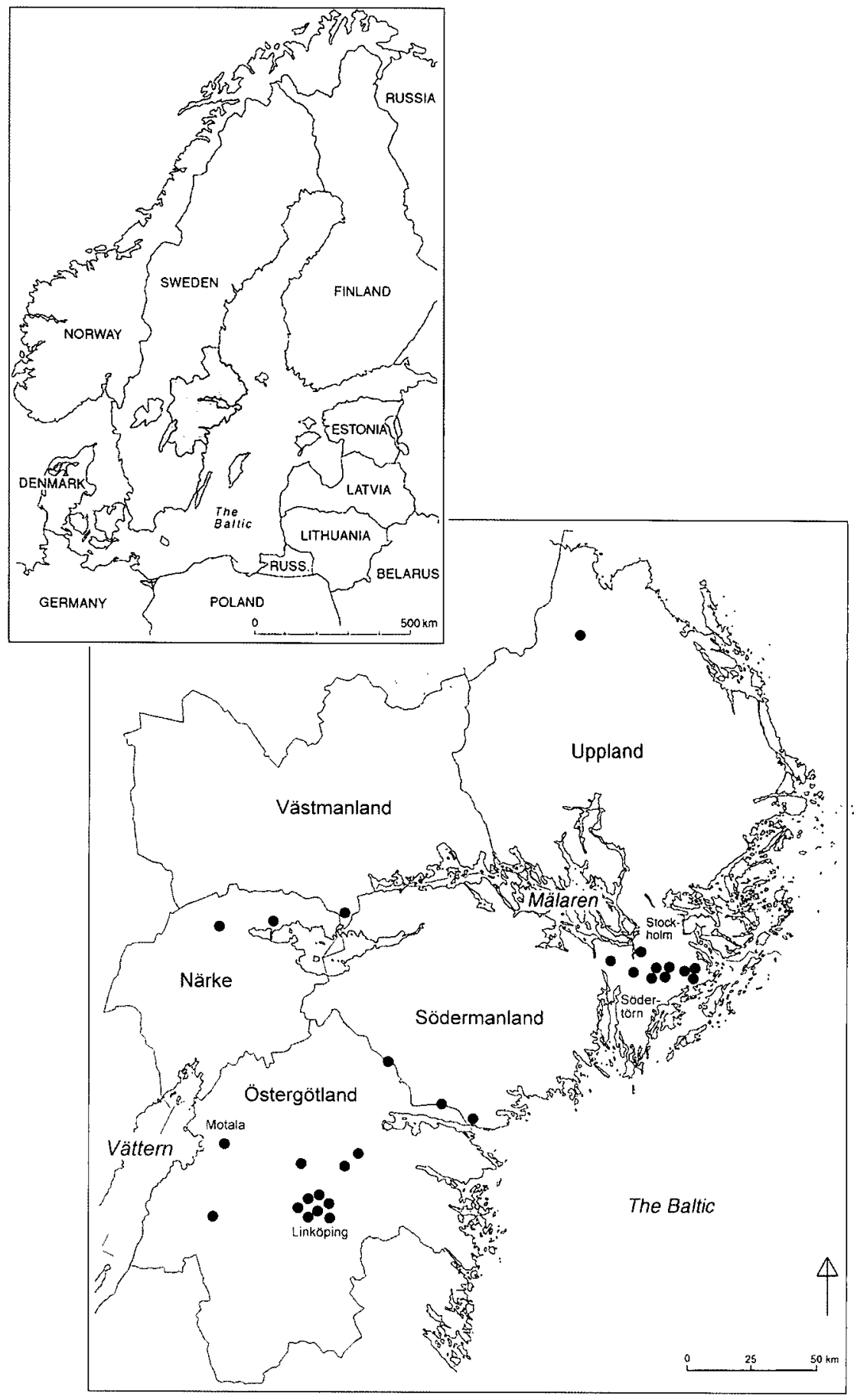

Fig. 1. Map of northern Europe and the Baltic. The shaded area marks the region of eastern middle Sweden. The dots indicate Mesolithic sites with traces of microblade technology in quartz. Graphics: Lars Östlin. 
Mesolithic sites have been found in all parts of the region, both on the coast of that time period and the mainland beyond, as well as in the very outermost archipelagos. Generally, quartz dominates the find material on all sites during the entire Mesolithic, but to the greatest extent on sites located in the coastal area and the archipelagos (Lindgren 2004). Sites on the mainland typically exhibit a slightly wider range of lithic material. This is a generalization, and the more exact picture is somewhat dependent on which part of the Mesolithic that is studied.

Another common trait for archipelago and mainland sites is the typical location to ancient shores: on the mainland the shores of lakes and water courses, in the archipelago the seashore. The latter is supported by numerous ${ }^{14} \mathrm{C}$-dates and can be used as a rough dating instrument - the higher a site is situated, the older it is (Åkerlund 1996; Pettersson \& Wikell 2004). For example, the highest sites on the Södertörn peninsula in the region's far east are situated 80 metres above the present sea level, indicating an age of between 8500 and $8000 \mathrm{cal} \mathrm{BC}$ (Hammar \& Wikell 1994, 1996; Gustafsson 1998).

The generally more varied lithic inventory of the mainland includes, for example, flint, tuff, quartzite and silicified tuff (Swe: hälleflinta). In this area, microblades and microblade cores, typically in the shape of handle cores, occur regularly, indicating a connection with the Scandinavian microblade tradition ( $c f$. Welinder 1977; Holm 2003a, b; Pettersson \& Wikell 2006c). In the archipelago, on the other hand, few microblades have been reported and extremely few microblade cores, a condition which has been the subject of different interpretations. The microblades have been interpreted as not manufactured in the archipelago but imported to the area as parts of ready-made composite tools. This would support the idea that the archipelago contained a local human population that marked its social identity against the mainland through material culture, in this case a puritan quartz industry with no traces of microblade production (Lindgren 2003). We would be dealing with a mainland and an archipelago group respectively, in a sense replacing Welinder's $(1973,1977)$ flint and quartz groups. An alternative interpretation is that different raw materials and techniques were used in different environments by one and the same population moving between the mainland and the coast/archipelago (Gill 2003; Schmitt 2003).

In the following, we will study two areas of the region more closely:

1) The Mesolithic mainland in the province of Östergötland including a nearcoast inner archipelago, and

2) The Mesolithic island world in the province of Södermanland, with focus on the outermost archipelago in the area of the present-day Södertörn peninsula.

\section{Microblades}

Blades can be defined as narrow flakes where the length is at least twice the width. According to established definitions, microblades are at the most 50-60 $\mathrm{mm}$ long and $10 \mathrm{~mm}$ wide (Bille Henriksen 1976; Larsson 1978; Olofsson 1995; 
Nordqvist 1999). However, there is much confusion about definitions and terms. What traditionally have been labelled microblades and microblade cores in Scania and Denmark have often meant something else when the same terms have been used in middle Sweden and Norrland.

In later research there is more concordance among different scholars. Also, further criteria for the classification of blades have been added, for example regarding knapping methods and the morphology of the striking platform (Nordqvist 1999; Knarrström 2000).

Microblades from different types of cores can be distinguished by the fact that blades from handle cores predominantly are curved as opposed to blades produced from other types of microblade cores, which are typically straight in profile.

During the Mesolithic of southern Scandinavia, microblades were predominantly retouched into microliths or used as cutting and scraping edges in composite tools (Olofsson 2002:74). During the late Mesolithic they are typically connected with the manufacturing of slotted bone-points. If we look at eastern middle Sweden there is evidence of an early microblade industry, $c$. 8000-6500 cal BC, but in contrast to the rest of southern Scandinavia there are only few finds of microliths, and no micro-burins are known to the authors. A few finds from the province of Östergötland indicate that these early microblades probably were made from conical cores (Browall 1999:293; Larsson \& Molin 2000).

During the middle and late Mesolithic, c. 6500-4200 cal BC, a microblade industry based on handle cores appears in the mainland area of the region. This indicates continuous contacts with areas to the southwest, where handle cores were introduced slightly earlier, at the end of the Boreal chronozone $c .7000 \mathrm{cal}$ BC (Knutsson 1995; Carlsson et al. 1999; Browall 2003:26 p; Holm 2003b; Eriksson 2005).

The appearance of the handle core could indicate new methods and strategies of reduction.

Its characteristic shape, with the drawn-out rear, facilitates both holding in the hand and the mounting of the core in some kind of wooden support, thus making it easier to use indirect techniques and pressure flaking methods of reduction (Sørensen 2003:148).

\section{The Motala site}

A large Mesolithic site excavated in Motala in the province of Östergötland exemplifies the microblade tradition in the mainland area of the region (Carlsson et al. 2003; Eriksson 2005). The activity on the site can mainly be dated to 5900$4000 \mathrm{cal} \mathrm{BC}$, though a few artefacts and dates indicate sporadic human presence as early as $c .8000 \mathrm{cal} \mathrm{BC}$.

The raw material for microblade production was ultramylonite and a number of different flints. Many of the quartzite microblades originated from handle cores, and this core type was also represented in the find material with a number of specimens. 
Flint does not occur in eastern middle Sweden, which is why all the flint on prehistoric sites is imported from other regions. The commonest flint in Motala was Cambrian flint from the area of Mt. Kinnekulle in the province of Västergötland. Also south Scandinavian flint, Kristianstad flint from eastern Scania and bryozoan flint from Denmark, were represented in the material (Eriksson 2005).

The microblade cores from the site were identified as bipolar cores, conical cores, handle cores and other cores. A special study showed that the majority of the "microblades" of Cambrian flint were produced with the bipolar method using hammerstones. South Scandinavian flints, on the other hand, were predominantly worked using an antler punch or pressure flaker (Eriksson 2005:100). Finds of pressure flakers are not uncommon on sites with ground conditions favourable for the preservation of organic matter. In fact, the Motala site yielded a complete pressure flaker made of Red Deer antler, ${ }^{14} \mathrm{C}$-dated to 4500 cal BC (Bergstrand 2005:67).

It was noted that a majority of the handle cores from the Motala site were very small, and thus during their final stages of reduction they produced microblades no longer than $10 \mathrm{~mm}$. It was questioned whether many of these very small blades actually could have been used as projectile points or for insertion in slotted bone points (Eriksson 2005:110).

\section{Bipolar cores}

Often, two types of bipolar cores occur on Mesolithic sites in the region. The first type is the result of a reduction where the force is directed straight into the core; the energy is transmitted to the material via two opposing percussion edges. During the reduction, this core diminishes in both height and width but retains its proportions and typical "cushion-like" form. The second type is a core that is reduced "outside-in" at the edge of a diagnostic platform. Both types are reduced with direct percussion using a hammerstone. Often, the "outside-in" type of bipolar core bears striking resemblance to blade cores such as conical, cylindrical and handle cores. A relevant question is whether the handle-core-like ones could be prefabricates for real microblade handle cores in those cases where they are found in contexts with quartz microblade production.

The fact that there are different types of bipolar cores indicates an active strategy in the bipolar reduction. Many bipolar flakes are thin, narrow and straight and only occasionally curved. The question has been raised by some scholars whether the narrow bipolar flakes are in a wider sense microblades, produced for the same purpose and function as these (cf. Werthwein 2000; Wikell 2005:91). With the bipolar method, microblade-like flakes could be easily produced, thus from our perspective making traditional microblade production from platform cores unnecessary. The keeping to microblade production sensu stricto might therefore instead be explained in terms of culture, tradition and ritual (Knutsson et al. 2003; Holm 2003a). 
A number of researchers have pointed out the problem with classification of microblades and microblade technology in quartz (Holm 2003a:115). The reduction of quartz, regardless of the method, produces a waste of which some pieces easily could be misidentified as microblades (Apel 1996:59). To be certain that a site contains indisputable traces of quartz microblade technology, one must have found microblades as well as microblade cores and/or rejuvenation flakes with negatives from microblades.

\section{MICROBLADE TECHNOLOGY IN THE ARCHIPELAGO}

The Stone Age archipelagos of eastern middle Sweden were of different character. The main focus will be the former archipelagos of the province of Södermanland. This is the part of the region that, during the Mesolithic, had the most pronounced geographical setting suitable for a specialized marine culture - thousands upon thousands of islands in an area measuring roughly $150 \times 50 \mathrm{~km}$.

Firstly, we will take a look at finds from islands and small archipelagos near the mainland coast. An early published find of a handle core with traces of microblade reduction (different information about raw material) from Lyttersta in the province of Södermanland has been geologically dated to the time of the first Litorina transgression, c. $7000 \mathrm{cal} \mathrm{BC}$, but is uncertain (Florin 1955; Knutsson et al. 1999; Apel et al. 2004). The find location was situated in the Mesolithic inner archipelago. Another site, recently excavated, at Ändebol in the southern part of the province, with a geographical location similar to Lyttersta, yielded a find material with greenstone and quartz including fragments of quartz microblades and a fragmentary microblade core (Gustafsson 2006). From the site Myskdalen in Kolmården yet another quartz microblade core, of handle-core type, has been collected (Bengtsson 2001).

In the provinces of Närke and Västmanland, a number of near-coast archipelagic settlements have been investigated. At Kuphälla a small microblade core of smoke quartz was found (Holm 2003a:112; Graner \& Luthander 2005), and at Skumparberget a knapping floor containing a number of quartz microblades and cores was excavated (Apel 1996). Another quartz microblade core has recently been found near a previously known site by the lake Gilsåssjön in Kilsbergen (J. Holm pers. comm.). Further northeast along the ancient coastline, sites investigated at Stormossen in the northern part of the province of Uppland contained microblades and microblade cores in tuff and quartz. During the time of occupation, the late Mesolithic, these sites were located in a small isolated archipelago $20 \mathrm{~km}$ east of the mainland (Guinard \& Eriksson 2005). All these sites were situated in a marine environment, but in rather small archipelagos near the mainland. The sites are probably the result of seasonal visits by people from the mainland.

From the real archipelago in eastern Södermanland, microblade cores and microblade core fragments have previously been reported from only a few places on the Södertörn peninsula. Microblades have been found at a number of excavated sites, but in small numbers (e.g., Drotz \& Ekman 1998; Lindgren 1996). 
The relative absence of microblade cores in the Södermanland archipelago compared with the mainland has been interpreted as if there were no significant production of microblades in the archipelago. Not a single handle core is registered from the two recent decades of extensive excavations of Mesolithic sites on the Södertörn peninsula (cf. Knutsson et al. 1999; Lindgren 1997; Åkerlund 2001), not even in the last 40 years (Olsson \& Åkerlund 1987). The find materials range from a handful, to some hundreds, to tens of thousands of quartz pieces at the largest sites ( $\AA$ kerlund 1996:39; Lindgren 2004:39).

There are, however, exceptions. Two quartzite handle cores were surfacecollected by the archaeologist Sven-Gunnar Broström in the western part of the Södertörn peninsula (Broström 1996, 2004). At Sjövreten a quartz microblade core was reported (Welinder 1973), and frontal fragments of microblade cores were found at the site Myrstugeberget (Granath Zillén 2001) and the large site Eklundshov. The latter site has dates from two phases, which is why the core fragment cannot be more precisely dated. However, Christina Lindgren is of the opinion that the artefact in question is from the older phase, around $7000 \mathrm{cal} \mathrm{BC}$ (Lindgren 2004).

In a recent excavation at the site Ungfars kärr in Tyresta National Park in the eastern part of the Södertörn peninsula, a number of microblades were found. They are of different materials such as quartz, quartzite and both Cambrian and south Scandinavian flint. Of importance is that removed proximal parts were obtained through meticulous water sieving. We interpret these proximal parts as an indication that microblades have been handled in the production and/or reedging of composite tools (Pettersson \& Wikell 2006a). This is a more complex usage of microblades than has previously been registered in the archipelago; earlier, the microblades from Södertörn have been interpreted as deriving from imported ready-made tools (Lindgren 1996, 2004:71). However, already the occasional previous finds of microblade core fragments from the Södertörn peninsula suggested that microblade technology was far more common than could be read from the scanty material hitherto obtained. The few finds literally drowned in the mass of knapped quartz.

Let us reflect on how our knowledge has been built up. Previously, one did not expect to find quartz microblade cores on the Södertörn peninsula - and consequently none were found. And, being too critical, one didn't dare to believe in the few specimens that now and then were actually observed. This is why they have not been correctly classified or published (cf. Knutsson 1998). As for the present authors, we have over the years observed many interesting cores, but especially in the early years these were unfortunately put aside with no further comment. However, as the observations have increased we have started to actively search for these artefacts, because they give new insights into the lithic craft and the cultural and social conditions in the region. The increasing number of quartz microblade cores from the Södermanland archipelago thus becomes more and more important. 
During recent extensive field surveys on the Södertörn peninsula, a number of quartz microblade cores were found. These cores seem to be quite common in the archipelago. A quartz microblade core from the site Smörasken, Tyresta National Park, is a good example (Fig. 5). It is of high-quality milky quartz, the narrow blades removed from a semi-circular front. The platform edge is neat, with no signs of crushing and with small and distinct negatives from the removed blades, indicating that a pressure flaker or punch was used. The core was found at approximately $55 \mathrm{~m}$ above the present sea level, indicating a shoreline date to $c$. $7000 \mathrm{cal} \mathrm{BC}$. A majority of the other cores found during the special surveys are between 60 and $50 \mathrm{~m}$ above the present sea level, in a shore-bound context corresponding to the long time-span 7300-5000 cal BC, though there are also occasional finds around 70 metres $(7400 \mathrm{cal} \mathrm{BC})$.

The dates, which are based on a shore displacement curve published by Jan Risberg (2003), are supported by some new ${ }^{14} \mathrm{C}$-dates. From the above-mentioned site Ungfars kärr, a hazelnut shell was dated to $7560+/-65$ BP (Ua-22783). The calibrated age is around 6450 BC (Pettersson \& Wikell 2006a:160, 2006b:152). A similar date has also been obtained from the previously mentioned site Ändebol in the southwest part of the province of Södermanland, 6450-6260 cal BC (Gustafsson 2006:13).

A detailed study of the material, including an analysis of the lithic technology, is necessary before any more general conclusions can be made. These scattered observations are only primary results. It is, however, clear that a microblade technology was present in the archipelago. Most probably, there is a hitherto unnoticed material in Stone Age collections in museums, not least in the large find material from excavations on the Södertörn peninsula.

Evidently, a microblade technology based predominantly on quartz was probably established already before $7000 \mathrm{cal} \mathrm{BC}$ in the island world of presentday Södermanland, both among the outermost islands and the mainland coast.

\section{MICROBLADES ON THE MAINLAND}

The province of Östergötland constitutes the region's southern part and in this paper exemplifies the mainland during the Mesolithic. The question about culture and regionality in the province's Mesolithic has recently been the subject of a synthesis based on investigations carried out by the National Heritage Board. The discussion mainly focuses on observations of the find material but also site location and spatial structures (Gruber 2005).

As in the region on the whole, local rocks dominate the lithic material, especially quartz. Still, considerable amounts of flint sometimes occur in the find materials. A number of finds of leister points, harpoons, antler tools, and carved items of bone and antler, as well as handle cores with triangular cross-section, indicate contacts with south Scandinavian traditions. This is especially true for the western part of the province, at the lakes Vättern and Tåkern. 
Several excavated sites have yielded well-preserved remains of huts and houses, something that is still completely lacking in the Södermanland archipelago (Åkerlund 2001; Carlsson 2005; Molin in press). To sum up, the province of Östergötland is a borderland with influences from different directions (Browall 1999:293, 2003:21 pp; Carlsson et al. 2003; Larsson \& Molin 2000; Carlsson et al. 2005).

There is evidence of microblades and microblade technology from at least 20 sites in Östergötland. Half of these contain indisputable traces of quartz microblade production in the form of cores and rejuvenation flakes. Nearly all the sites are located along the mainland coast or in the inner archipelago. The coastal sites lie between 75 and $40 \mathrm{~m}$ above the present sea level, giving a rough shoreline dating to $8000-4200 \mathrm{cal} \mathrm{BC}$. One of the earliest datings of quartz microblade technology, $8300-6700 \mathrm{cal} \mathrm{BC}$, comes from Mörby in the western part of the province (Kaliff et al. 1997).

Especially in the area around the town Linköping, many sites have recently been discovered with an indisputable quartz microblade technology. Most of these sites are located on moraine hills, which during the middle and late Mesolithic were islands in an inner archipelago of the Litorina Sea. A majority of the sites have been interpreted as the remains of specialized hunting and fishing stations with no traces of more permanent occupation. Interestingly, one of these sites, Stjärneberg, contains the only Mesolithic quartz quarry hitherto investigated in Östergötland (Molin et al. in press). Larger site complexes with remains of both huts and houses have been found nearby on the Mesolithic mainland coast (Molin 2006, Molin in press).

\section{AN ANALYSIS OF LITHIC TECHNOLOGY}

The studied material comes from seven sites, four of which have been excavated and three surface-collected. Of the excavated sites, the main focus is on two, Trädgårdstorp and Köpetorp. Trädgårdstorp is a large settlement complex in connection with the Mesolithic coastline. The investigation included two wellpreserved Mesolithic house or hut remains (Molin 2006, Molin in press). A large number of ${ }^{14} \mathrm{C}$-dates place the occupation between 7500 and $5700 \mathrm{cal} \mathrm{BC}$. Quartz microblade production is firmly indicated in the oldest settlement phase, c. 7500 $7000 \mathrm{cal} \mathrm{BC}$. The site at Köpetorp was at the time of occupation situated in the inner archipelago near the mainland. The height above the present sea level, 55 $\mathrm{m}$, gives a shoreline dating to c. $6500 \mathrm{cal} \mathrm{BC}$.

The study draws attention to dense, high-quality quartz as raw material and makes an attempt to understand quartz microblade technology. No study of the blades' function, such as use-wear analysis, has been made. The chosen material contains 21 complete or fragmentary microblade cores, 30 complete or fragmentary microblades, and about 15 rejuvenation flakes. The rejuvenation flakes are of two main types: those that have been removed with a blow from below in order to create a new platform; and those that have been removed with a blow from above, 


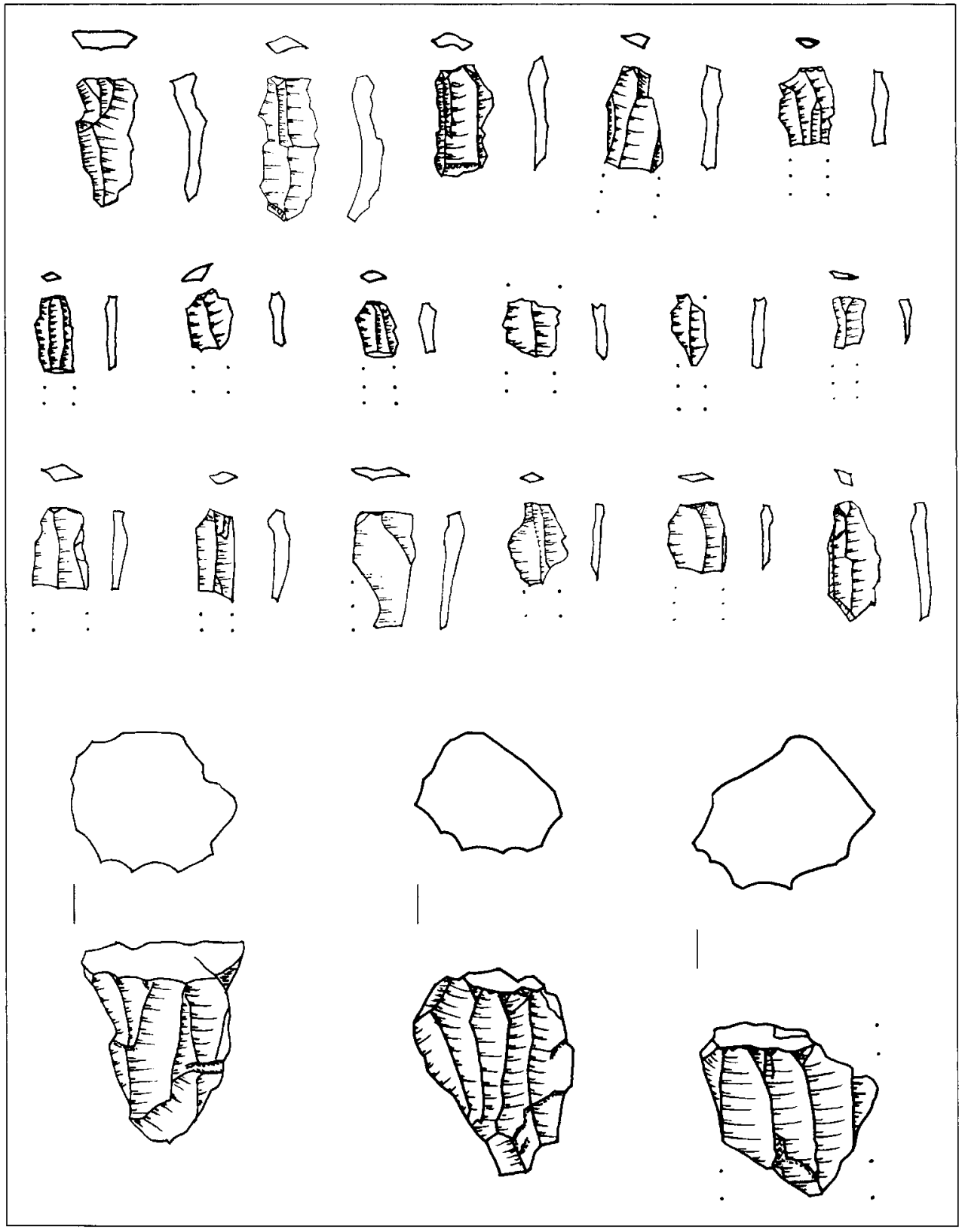

Fig. 2. Microblades and microblade cores of quartz from the site Köpetorp in Linköping. Scale 1:1. The drawing illustrates three cores of conical shape. The height above the present sea level, 55 metres, gives a presumed shoreline dating to c. $6500 \mathrm{cal}$ BC. Drawing: Fredrik Molin. 
against the platform "behind the edge", in order to create a new blade removal front. Both types exhibit negatives from blades. Several rejuvenation flakes clearly illustrate typical morphological attributes. For instance, from the site Köpetorp about 10 typical rejuvenation flakes have been collected, all of them removed with the platform method.

The microblades have been studied according to the following variables: fragmentation, length, width, thickness, dorsal ridges, platform trimming, size of platform remnant, and possible ventral lip. The following metrical and morphological attributes have been registered for the microblade cores: fragmentation, platform size and morphology, front height, and platform trimming.

The technological analysis can be summarised as follows:

\section{Microblades}

Trädgårdstorp. 8 blades (Fig. 3).

The raw material is milk quartz and prismatic, almost transparent, quartz. Two blades are complete, five proximal and one distal fragment. The two complete blades have a length of 12 and $13 \mathrm{~mm}$ respectively, the fragments $8-12 \mathrm{~mm}$. The complete blades exhibit traces from platform preparation in order to facilitate blade removal. All the blades have a straight profile and are $1.5-2 \mathrm{~mm}$ thick. The complete blades and proximal fragments have whole, small, and lens-shaped platforms and small percussion bulbs. Some of the platforms are pointed oval in shape.

Köpetorp. 22 blades (Fig. 2).

The raw material is prismatic, rock-crystal-like quartz. Four specimens are complete, ten proximal, seven medial and one distal fragment. The complete blades are 13-17 mm long, the fragments 6-14 mm. A few blades have traces of platform trimming. Two complete blades have curved profiles; the others are straight. Nearly all the platforms are small, and many are pointed oval in shape. Percussion bulbs are small and distinct. One blade lacks a bulb and has a large and irregular platform remnant, indicating the bipolar method.

All in all, the 30 blades vary between 4 and $8 \mathrm{~mm}$ in maximal width. The majority, however, are apparently standardized between 5.5 and $7 \mathrm{~mm}$. No blade is thicker than $2.5 \mathrm{~mm}$.

From the morphological attributes the knapping method can be identified as soft technique using a pressure flaker or indirect technique by antler puncher. Nothing, apart from a single blade, indicates the bipolar method with hammerstone.

The production seems to be standardized with straight blade parts, $10 \mathrm{~mm}$ long, as the ideal final product. Even though distal parts of microblades often fracture off when indirect methods of reduction are used (Sørensen 2003:149), it seems obvious in the present case that curved and hence non-desirable distal parts have been deliberately removed from the blades. What remains is $\int$ of the blade's original length. 


\section{Microblade cores}

Of the 20 cores, half are complete and half fragmentary. The complete cores are of different types such as conical cores, handle cores and more irregular cores. Some of the handle cores exhibit a triangular cross-section, some two opposing platforms.

One singular core of dense milk quartz exhibits traces from both microblade technology sensu strictu and bipolar reduction (Fig. 5). The microblades have been removed from a clearly convex platform (the only convex in the entire studied material). The core front is $15 \mathrm{~mm}$ high. The core is on the whole pillowshaped with a number of narrow bipolar "blade" negatives. It is obvious that narrow microblade-like flakes have been produced with a bipolar method here. When carefully examining the negatives it appeared that the bipolar flakes had very small or crushed platforms and no percussion bulbs as opposed to the produced microblades.

At the site Köpetorp, three complete and four fragments of microblade cores were collected. The cores are either of dense milk quartz or excellent, glossy prismatic quartz. All cores are deliberately shaped. Two cores are conical, 24 and $22 \mathrm{~mm}$ high respectively, with blade removal fronts along $\int$ of the platforms. The platforms are almost flat or only slightly concave and measure between 17

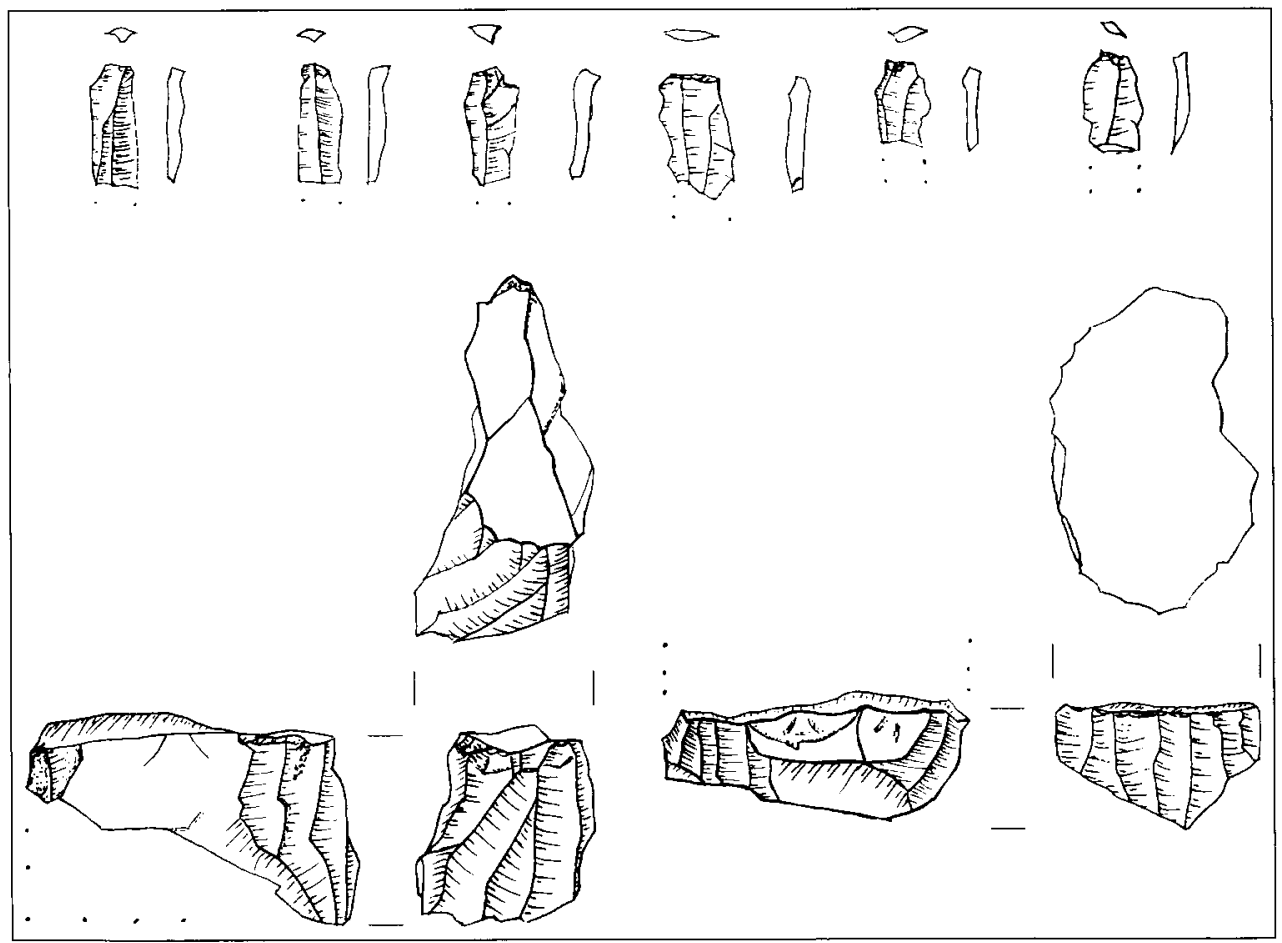

Fig. 3. Microblades and microblade cores of quartz from the settlement site Trädgairdstorp in Linköping. Scale 1:1. The drawing illustrates two cores of handle-core-like type. The settlement is dated to between 7500 and 5700 cal BC. Drawing: Fredrik Molin. 
and $22 \mathrm{~mm}$ at the most. None of the platforms have traces of trimming. The core fragments with remaining parts of the platform and front are metrically and technologically similar to the complete cores. One core fragment resembles the front of a handle core. A small microblade core of milk quartz is of almost cubic shape with two opposing platforms (Fig. 5). The produced microblades were 13$14 \mathrm{~mm}$ long and spalled from three fronts. The platform measures $18 \times 15 \mathrm{~mm}$ and has uncertain traces of preparation along the edges.

The three cores from Trädgårdstorp are of another style. They are handlecore-like and deliberately shaped. The raw material is dense, high-quality, prismatic quartz. One core is complete, while two are fragments. The complete core has a flat platform, $20 \times 20 \mathrm{~mm}$, and a steep front, $21 \mathrm{~mm}$ high. The core resembles the frontal part of a handle core. There are no traces of platform trimming.

The fragmentary cores exhibit more oblong shapes, the original complete cores probably being between 32 and $33 \mathrm{~mm}$ long. One specimen is the upper part, with platform and front remnants, of a microblade core that has been dismembered with the bipolar technique. The front is $20 \mathrm{~mm}$ high. The platform is flat with faint traces of trimming. Another fragment is indisputably the lower part of a handle core with remnants of two opposing fronts. Crush marks on both ends indicate that the core has been split in half like a bipolar core. The fronts measure 11 and $6 \mathrm{~mm}$ respectively and have clearly curved profiles. Thus, the blades produced from this core had curved distal ends.

Two handle-core-like cores of quartz from the sites Kallerstad and Mörtlösa Södergård in the Linköping area are made from round-worn nodules. The sites were at the time of occupation located on small islands in the inner archipelago, 40 and $45 \mathrm{~m}$ above the present sea level respectively, the shoreline dating them to the late Mesolithic.

The core from Kallerstad is of smoke quartz and has two opposing raw surfaces as platforms. The platform from which the blades have been removed measures $29 \times 17 \mathrm{~mm}$ and shows no trace of trimming. Negatives from spalled blades are present on the front and along one side. The front is $20 \mathrm{~mm}$ high. Also at Kallerstad, a conical microblade core of transparent, prismatic quartz has been collected. The core is $26 \mathrm{~mm}$ high and the platform measures approximately $15 \mathrm{~mm}$. The platform edge shows faint traces of trimming.

The handle core from Mörtlösa Södergård has a triangular cross-section in the worked frontal half and a concave natural platform measuring $25 \times 20 \mathrm{~mm}$ (Fig. 5). Removal scars from microblades are present on the front and along one side. The front is $17 \mathrm{~mm}$ high at the most. The raw material is dense, grey-white, milk quartz with suffusions of red feldspar.

Finally, two quartz microblade cores and three rejuvenation flakes from Hultet I, a surface-collected site in the western part of the province, should be mentioned (Molin 2005:147 pp). All collected material from this site is of dense milk quartz. One of the cores has a conical shape whereas the other is handle-core-like with a triangular cross-section. Both are deliberately shaped with more or less flat 


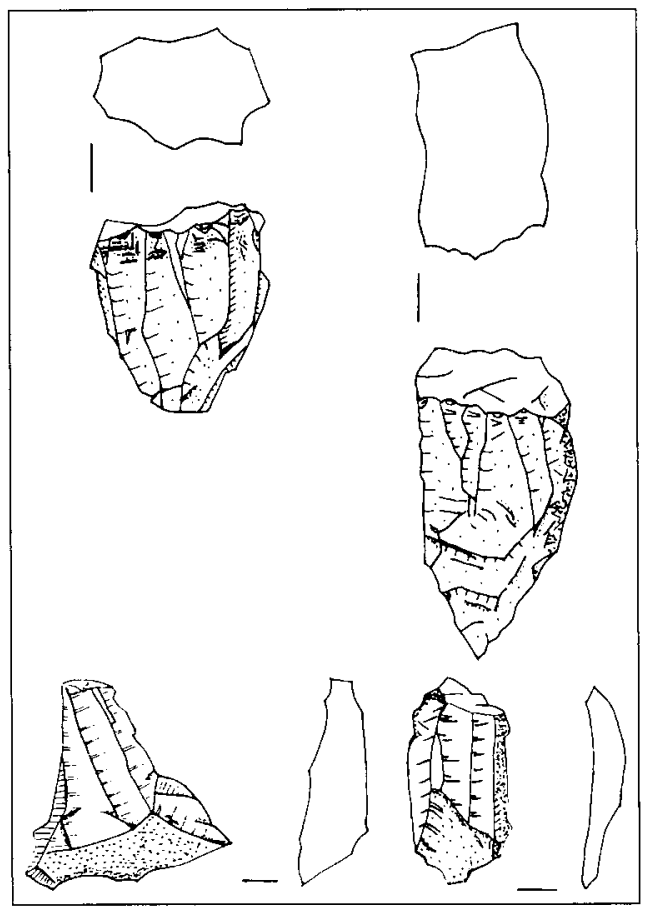

Fig. 4. Two microblade cores and rejuvenation flakes of quartz from the surface-collected site Hultet I, near Motala. Scale 1:1. The height above the present sea level, 75 metres, gives a presumed shoreline dating to c. 7500 cal BC. Drawing: Fredrik Molin.

platforms measuring $12 \times 16$ and $16 \times$ $23 \mathrm{~mm}$ respectively. The topography and terrain position indicate a location near the mainland seashore. The height above the present sea level, $75 \mathrm{~m}$, would give a shoreline dating to $c$. 7500 cal BC.

To sum up, the study shows that the quartz microblade cores from the province of Östergötland are of different types, including conical cores and handle cores. It is also obvious that some blanks were chosen among loose nodules that had natural suitable platforms and fronts. Other cores are deliberately shaped. The common attribute is the occurrence of a flat or concave platform and a functional angle between the platform and core front. Among the handle cores, both types with triangular cross-sections and opposing platforms are represented. Morphological attributes such as diagnostic platform trimming, and small, lens-shaped and complete platform remnants on blades, indicate predominance for soft or indirect techniques with a pressure flaker or antler puncher.

The microblade production in the Linköping area seems to be standardized, with straight, $10 \mathrm{~mm}$ long sections of microblades as the desired final product.

Many cores in the study bear resemblance to conical and handle cores, even though these shapes may not necessarily have been desired. The quartz microblade technology on the region's mainland can probably be dated to $7500-4200$ cal BC. Handle cores are from a morphological perspective present already in the earliest phase.

\section{SUMMARY AND DISCUSSION}

Two areas within the region of eastern middle Sweden with different paleogeography have been closely examined in this paper: the archipelago of the present-day province of Södermanland, and the mainland in the province of Östergötland. The earlier proposed cultural differences between the areas have stressed differences in lithic raw material, technology as well as economy and site location. Quartz as raw material for tool making may instead be seen as an attribute 
uniting the two areas. In a broader sense, this probably reflects a common archipelagic culture with communications over greater distances.

In the Mesolithic archipelago of present-day Södermanland, quartz dominates the lithic material; during the Mesolithic it was reduced with both the bipolar and the platform technique. Until very recently, microblade production was not observed in this area. The finds of microblades, typically of flint, were interpreted as pieces of imported composite tools. However, when looking at new source

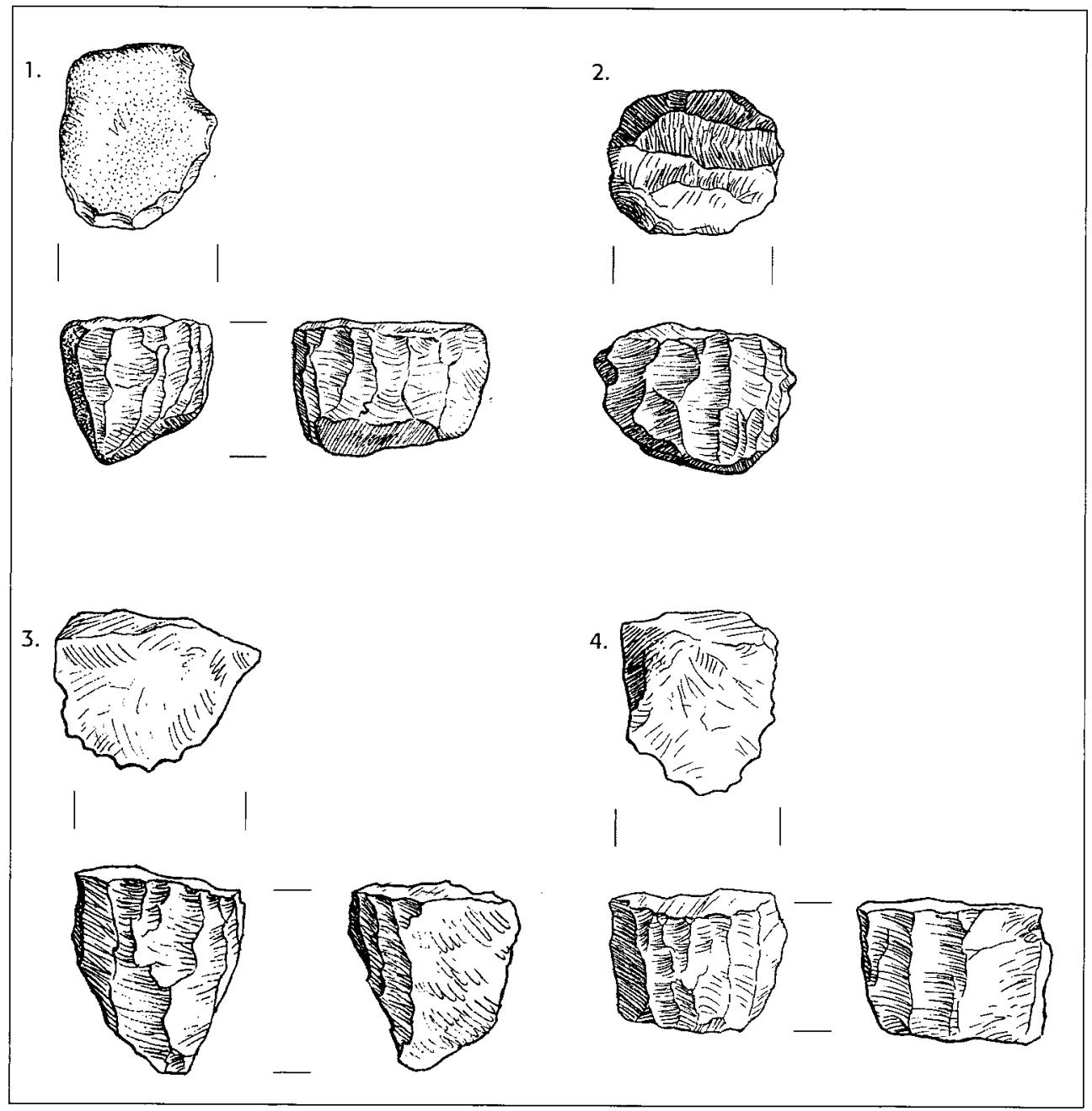

Fig. 5. Examples of microblade cores of quartz of different shapes from eastern middle Sweden. Scale 1:1. 1. Late Mesolithic handle core from Mörtlösa Södergaird in Linköping. Note the triangular cross-section. 2. Microblade core from Kungsbro, northwest of Linköping, with traces of both bipolar and microblade technology 3. Microblade core from the site Smörasken in Tyresta National Park. Note the races of namow blades removed from the semi-circular front. The height above the present sea level, 55 metres, gives a prestmed shoreline dating at Södertörn to c. 7000 cal BC. 4. A small microblade core of almost cubic shape, with two opposing platforms. From the site Köpetorp in Linköping. Drawing: Mattias Pettersson. 
material, including a re-evaluation of older finds as well as new finds from fieldsurveys, it is obvious that microblade production occurred quite regularly in this area. A number of quartz microblade cores and sites containing microblades and specific production waste confirm this.

Östergötland constitutes the southernmost part of the region and exemplifies the mainland and the near-coast inner archipelago. Culturally the province is somewhat of a borderland, where cultural impulses from different directions blended. The find materials are dominated by quartz and local rocks, but there is also a considerable amount of flints, especially in the western part of the province, indicating contacts with south and west Scandinavia. Microblade production is a common element at many sites during the entire Mesolithic.

In the region of eastern middle Sweden, the quartz microblade tradition can, as far as we know, be dated to $7500-4200$ cal BC. Quartz microblade cores from Östergötland are of varying types, with some resembling conical cores or handle cores. These forms also appear among the few microblade cores from Södermanland, but less regularly.

The question is whether the handle cores of the region chronologically and in a context of cultural meaning belong to the defined handle-core tradition. And did the quartz microblade craft in eastern middle Sweden correspond to the microblade tradition in southern and western Sweden? There are many irregular cores, where design as such doesn't seem to have mattered. Rather, it seems as though the shapes of quartz microblade cores in the studied areas were generally functional and not expressions of cultural identity. This hypothesis could be examined with experimental knapping sequences in order to study knapping techniques and the morphology of blades, cores and debris (K. Knutsson pers. comm.).

Another interesting fact is that small bipolar cores reduced with direct hard technique generate narrow and thin flakes that closely resemble microblades and with no functional difference from these. With the bipolar method, "microblade substitutes" could be produced faster and more easily, thus making traditional microblade production from classical platform cores unnecessary. The keeping to microblade production in quartz sensu stricto could possibly instead be explained in terms of culture, tradition and ritual.

The conservatism in the use of quartz as a raw material in the archipelago during the Mesolithic gives this area a cultural identity. But also on the mainland, quartz was widely used. The question is therefore polarized between two extremes: whether raw material choice has to do with cultural traditions, or if it is an adaptation to local conditions. Probably we see the result of a complex behaviour somewhere between the two in the choice of lithic raw material.

The previously proposed (Lindgren 2003) division into an archipelago group and a mainland group appears somewhat less sharp now that the microblade technology has been observed in both areas. As archaeologists we have thus closed a circle. At first, researchers looking at quartz materials tried to find artefact 
types known from flint industries. When this failed, fracture analysis emerged and helped the interpretation of the find materials (Callahan 1987; Callahan et al. 1992). But during the initial classification of the frequently large quantities of quartz, more unusual methods of knapping and retouching were often disregarded. This is also true for the focus of this paper: microblade technology in quartz. One searched for certain attributes - and disbelieved others as being flint morphology translated into quartz. A too critical view of more specialized quartz craft soon spread among east middle Swedish scholars. The fact that "reading quartz" is troublesome for the beginner has long since been recognized (Lindgren 1998; Olofsson 1995; Wikell 2005). Now, with the increasing knowledge of quartz, microblade production has been identified at many places in the region.

According to Olofsson, microblade technology is a circumpolar cultural trait with a vast geographical and chronological distribution (Olofsson 2002:74). The handle-core tradition has in eastern middle Sweden traditionally been dated to the late Mesolithic. It is obvious, however, that the local production of microblades from different core types spans a much longer period. Perhaps the production of quartz microblades should be seen as an expression of a common cultural identity among the people of the archipelago and mainland areas of Mesolithic eastern middle Sweden.

Translation by Mattias Pettersson, Lindesberg.

ACKNOWLEDGEMENTS

Core consultation by Kjel Knutsson, Uppsala University.

Patrik Gustafsson, Sörmlands Museum.

\section{REFERENCES}

Akerlund, A. 1996. Human Responses to Shore Displacement: Living by the Sea in Eastern Middle Sweden during the Stone Age. Riksantikvarieämbetet, Arkeologiska undersökningar, Skrifter 16. Stockholm.

Akerlund, A. 2000. Separate Worlds? Interpretation of the Different Material Patterns in the Archipelago and the Surrounding Mainland Areas of East-Central Sweden in the Stone Age. European Journal of Archaeology 3/1. Pp. 7-29.

Åkerlund, A. 2001. Stenålder i Östra Mellansverige: undersökningar utförda under de senaste decennierna. In: Bergenstråhle, I. \& Hellerström, S. (Eds). Stenäldersforskning i fokus. Riksantikvarieämbetet, Arkeologiska undersökningar, Skrifter 39. University of Lund, Institute of Archaeology, Report series nr 77. Pp. 47-60. Lund.

Apel, J. 1996. (Ed). Skumparberget 1 och 2: en mesolitisk aktivitetsyta och tidigneolitiska trattbägarlokaler vid Skumparberget i Glanshammars sn, Örebro län, Närke. För-och slutundersökningsrapport från Arkeologikonsult $A B$.

Apel, J., Falkenström, P., Guinard, M. \& Nordin, M. 2004. Lyttersta 2. En stenålderslokal i Västra Vingåker. Arkeologisk förundersökning. RAÄ 488, Sävstaholm 7:2, Västra Vingåker sn, Södermanland. SAU Rapport 2004:2. Uppsala.

Bengtsson, L. 2001. Stenstugan och Myskdalen. Arkeologiska förundersökningar och undersökning - två stenåldersboplatser $\mathrm{i}$ Kolmården: väg 511, Södermanland. Riksantikvarieämbetet. Avdelningen för arkeologiska undersökningar. Rapport UV Mitt 2001:18. 
Bergstrand, T. 2005. Leister fishing in Motala ström during the Atlantic period. A typological study based on the finds from the Motala site, Östergötland. In: Gruber, G. (Ed). Identities in transition. Mesolithic strategies in the province of Östergötland. Riksantikvarieämbetet, Arkeologiska undersökningar, Skrifter 64. Pp. 54-75. Linköping.

Bille Henriksen, B. 1976. Svcerdborg 1. Excavations 1943-44: Settlement of the Maglemose Culture. Arkæologiske Studier III. Copenhagen.

Broström, S-G. 1996. Inventering av stenåldersboplatser på västra Södertörn. In: Bratt, P.

(Ed). Stenålder i Stockholms län: Två seminarier vid Stockholms länsmuseum. Pp. 66-71. Stockholm.

Broström, S-G. 2004. Stenfynd på Södertörn. Sörmlandsbygden. Pp. 77-90. Nyköping.

Browall, H. 1999. Mesolitiska mellanhavanden i västra Östergötland. In: Gustafsson, A. \& Karlsson, H. (Eds). Glyfer och arkeologiska rum - en vänbok till Jarl Nordbladh. Pp. 289-303. Gotarc Series A 3 Göteborg.

Browall, H. 2003. Det forntida Alvastra. Statens Historiska Museum. Monographs 6. Stockholm.

Callahan, E. 1987. An Evaluation of the Lithic Technology in Middle Sweden During the Mesolithic and Neolithic. Aun 8. Uppsala.

Callahan, E., Forsberg, L., Knutsson, K. \& Lindgren, C. 1992. Frakturbilder: Kulturhistoriska kommentarer till det säregna sönderfallet vid bearbetning av kvarts. Tor 26. Pp. 27-63. Uppsala

Carlsson, T. 2005. Home, sweet home. The spatial story of Mesolithic settlement organization in Östergötland. In: Gruber, G. (Ed). Identities in transition. Mesolithic strategies in the province of Östergötland. Riksantikvarieämbetet, Arkeologiska undersökningar, Skrifter 64. Pp. 36-53. Linköping.

Carlsson, T., Kaliff, A. \& Larsson, M. 1999. Man and the Landscape in the Mesolithic: Aspects of Mental and Physical Settlement Organization. In: Boaz, J. (Ed). The Mesolithic of Central Scandinavia. Universitetets Oldsaksamlings Skrifter. Ny rekke 22. Pp. 47-72. Oslo.

Carlsson, T., Gruber \& G. Molin, F. 2005. The Mesolithic in Östergötland - An introduction. In: Gruber, G. (Ed). Identities in transition. Mesolithic strategies in the province of Östergötland. Riksantikvarieämbetet, Arkeologiska undersökningar, Skrifter 64. Pp. 8-23. Linköping.

Carlsson, T., Gruber, G., Molin, F. \& Wikell, R. 2003. Between Quartz and Flint: Material Culture and Social Interaction. In: Larsson, L., Kindgren, H., Knutsson, K., Loeffler, D. \& Åkerlund, A. (Eds). Mesolithic on the Move: Papers Presented at the Sixth International Conference on the Mesolithic in Europe, Stockholm 2000. Pp. 302-309. Oxford: Oxbow Books.

Drotz, M. \& Ekman, T. 1998. Jordbromalm - Säl- och vildsvinsjägare i Haninge. Riksantikvarieämbetet. Rapport UV Mitt 1998:48. Stockholm.

Eriksson, N. 2005. The flint from the settlement site in Motala. A study of raw material, technology and function. In: Gruber, G. (Ed). Identities in transition. Mesolithic strategies in the province of Östergötland. Riksantikvarieämbetet, Arkeologiska undersökningar, Skrifter 64. Pp. 100-113. Linköping.

Florin, S. 1955. Geologi och stenåldershistoria. In: Schnell, I. (Ed). Vingåkersboken del II. Västra Vingåkers hembygdsförening. Vingåker.

Gill, A. 2003. Stenålder i Mälardalen. Stockholm Studies in Archaeology 26. Stockholm.

Granath Zillén, G. 2001. Besökt och återbesökt: Arkeologisk undersökning, stenålders- och bronsåldersboplats vid Myrstugeberget, väg 259, Södermanland. Riksantikvarieämbetet. UV Mitt rapport 2001:8. Stockholm.

Graner, G. \& Luthander, A. 2005. Kuphälla: senmesolitiska besök på en ö i Käglans skärgård, Närke. Arkeologisk undersökning och kompletterande inventering. Riksantikvarieämbetet. Rapport $U V$ Bergslagen 2003:12. Örebro.

Gruber, G. (Ed). 2005. Identities in transition. Mesolithic strategies in the province of Östergötland. Riksantikvarieämbetet, Arkeologiska undersökningar, Skrifter 64. Linköping.

Guinard, M. \& Eriksson, M. 2005. Mesolitiska boplatser vid Stormossen. Slipstenar och vatillverkning $i$ den uppländska ytterskärgården för 6500 år sedan. Uppland 2005. Upplands fornminnesförening. Pp. 48-59. Uppsala.

Gustafsson, Per. 1998. The Earliest Stone Age Occupation of Eastern Middle Sweden. Current Swedish Archaeology Vol 6. Pp. 47-62. Stockholm.

Gustafsson, Patrik. 2006. Ändebol. Stora Malm 274 \& 275. Södermanlands län. Arkeologisk förundersökning. Sörmlands museum. Arkeologiska meddelanden 2006:13. Nyköping. 
Hammar, D. \& Wikell, R. 1994. Nyupptäckta stenåldersboplatser på Södertörn. Arkeologi i Sverige. Ny Följd 3. Riksantikvarieämbetet. Pp. 217-223. Stockholm.

Hammar, D. \& Wikell, R. 1996. 250 nyupptäckta stenåldersboplatser på Södertörn. In: Bratt, P. (Ed). Stenålder $i$ Stockholms län: Två seminarier vid Stockholms länsmuseum. Pp. 15-21. Stockholm.

Holm, J. 2003a. Handtagskärnor och kvarts. In: Karlenby, L. (Ed). Mittens rike: Arkeologiska berättelser. från Närke. Riksantikvarieämbetet. Arkeologiska Undersökningar, Skrifter 50. Stockholm.

Holm, J. 2003b. Quartz, Microblades and the Meaning of Life. In: Samuelsson, C. \& Ytterberg, N. (Eds). Uniting Sea: Stone Age Societies in the Baltic Sea Region. Pp. 79-88. Uppsala.

Kaliff, A., Carlsson, T., Molin, F. \& Sundberg, K. 1997. Mörby. Östergötlands äldsta boplats. Riksantikvarieämbetet. Rappont UV Linköping 1997:38. Linköping.

Knarrström, B. 2000. Flinta i sydvästra Skåne. En diakron studie av rämaterial, produktion och funktion med fokus på boplatsekonomi och metalltida flintutnyttjande. Acta Archaeologica Lundensia. Series in $8^{\circ}, 33$. Lund.

Knutsson, K. 1995. Mesolithic Research in Sweden 1986-1990. In: Buström, M. \& Carlsson, A. (Eds). Current Swedish Archaeology Vol. 3. Pp. 7-27. Stockholm.

Knutsson, K. 1998. Convention and Lithic Analyses. In: Holm, L. \& Knutsson, K. (Eds). Proceedings from the Third Flint Alternatives Conference at Uppsala. OPIA 16. Pp. 71-93. Uppsala.

Knutsson, K., Falkenström, P. \& Lindberg, K.F. 2003. Appropriation of the Past. Neolithisation in the Northern Scandinavian Perspective. In: Larsson, L., Kindgren, H., Knutsson, K., Loeffler, D. \& Åkerlund, A. (Eds). Mesolithic on the Move: Papers Presented at the Sixth International Conference on the Mesolithic in Europe, Stockholm 2000. Pp. 414-430. Oxford: Oxbow Books.

Knutsson, K., Lindgren, C., Hallgren, F. \& Björck, N. 1999. The Mesolithic in Eastern Central Sweden. In: Boaz, J. (Ed). The Mesolithic of Central Scandinavia. Universitetets Oldsaksamlings Skrifter. Ny rekke 22. Pp. 87-123. Oslo.

Larsson, L. 1978. Ageröd 1:B-Ageröd 1:D. A Study of Earty Atlantic Settlement in Scania. Acta Archaeologica Lundensia. Series in $4^{\circ}, 12$. Lund.

Larsson, M. \& Molin, F. 2000. A New World. Cultural Links and Spatial Disposition - The Early Mesolithic Landscape in Östergötland on the Basis of the Storlyckan Investigations. Lund Archaeological Review 6. Pp. 7-22. Lund.

Lindgren, C. 1996. Fyndkoncentrationer och aktivitetsytor - metodval och tolkningsproblem. In: Bratt, P. (Ed). Stenålder i Stockholms län: Två seminarier vid Stockholms länsmuseum. Pp. 29-37. Stockholm.

Lindgren, C. 1997. Östra Mellansverige. In the chapter: Regionalitet under Mesolitikum - Från senglacial tid till senatlantisk tid i Syd- och Mellansverige, by M. Larsson, C. Lindgren \& B. Nordqvist. In: Larsson, M. \& Olsson, E. (Eds). Regionalt och interregionalt. Stenåldersundersökningar i Syd-och Mellansverige. Riksantikvarieämbetet, Arkeologiska Undersökningar, Skrifter 23. Pp. 21-32. Stockholm.

Lindgren, C. 1998. Shapes of Quartz and Shapes of Minds. In: Holm, J. \& Knutsson, K. (Eds). Proceedings from the Third Flint Alternatives Conference at Uppsala. OPIA 16. Pp. 95-103. Uppsala.

Lindgren, C. 2003. My Way or Your Way: On the Social Dimension of Technology as Seen in the Lithic Strategies in Eastern Middle Sweden during the Mesolithic. In: Larsson, L., Kindgren, H., Knutsson, K., Loeffler, D. \& Akerlund, A. (Eds). Mesolithic on the Move: Papers Presented at the Sixth International Conference on the Mesolithic in Europe, Stockholm 2000. Pp. 177-183. Oxford: Oxbow Books.

Lindgren, C. 2004. Människor och kvarts. Sociala och teknologiska strategier under mesolitikum i östra Mellansverige. Stockholm Studies in Archaeology 29. Riksantikvarieämbetet, Arkeologiska Undersökningar, Skrifter 54. Coast to Coast Books 11. Stockholm.

Molin, F. 2005. Between Ancient Vättern and the Ancylus Lake. Early Mesolithic settlement in the Motala district in western Östergötland. In: Gruber, G. (Ed). Identities in transition. Mesolithic strategies in the province of Östergötland. Riksantikvarieämbetet, Arkeologiska undersökningar, Skrifter 64. Pp. 138153. Linköping.

Molin, F. 2006. Trädgărdstorp. Boplatslämningar från senneolitikum och bronsålder. Arkeologiska undersökningar inför återvinningscentral samt nytt skyttecentrum. Riksantikvarieämbetet. Avdelningen för arkeologiska undersökningar. UV Öst Rapport 2006:53.

Molin, F. In press. Along the shores of the Ancylus Lake. Trädgårdstorp and other coastal Mesolithic settlement sites during the Late Ancylus period in Western Östergötland. In: McCartan, S., Schulting, 
R., Warren, G. \& Woodman, P.C. (Eds) Mesolithic Horizons. Papers presented at the $7^{\text {th }}$ International Conference on the Mesolithic in Europe, Belfast 2005. Oxbow. Oxford.

Molin, F., Rolöf, M. \& Wikell, R. In press. Mesolithic quartz quarrying in Eastern Middle Sweden. The example of Stjärneberg, Linköping. In: Sternke, F., Eigeland, L. \& Costa, L-J. (Eds). Non-flint Raw Material Use in Prehistory - Old Prejudices and New Directions. XVth UISPP World Congress, Lisbon 2006.

Nordqvist, B. 1999. Spån och spånkärnor som kronologiska markörer. In Situ. Västsvensk Arkeologisk Tidskrift 1999. Pp. 113-118. Göteborgs universitet. Kungälv.

Olofsson, A. 1995. Kölshrapor, mikrospänkärnor och mikrospän: En studie med utgaingspunkt i nordsvensk mikrospånteknik. Arkeologiska studier vid Umeå universitet, 3. Umeå.

Olofsson, A. 2002. Microblade Technology in Northern Sweden. Chronological and Cultural Implications. Current Swedish Archaeology Vol 10. Pp. 73-94. Stockholm.

Olsson, E. \& Åkerlund, A. 1987. Stenåldersundersökningar i östra Mellansverige. In: Andrae, T., Hasselmo, M. \& Lamm, K. (Eds). 7000 air på 20 år: Arkeologiska undersökningar i Mellansverige. Riksantikvarieämbetet. Pp. 9-40. Stockholm.

Pettersson, M. \& Wikell, R. 2004. The Outermost shore. Site-location in Mesolithic seascapes of Eastern Central Sweden - With a case study in a burnt-off Forest Area in Tyresta National park. In: Knutsson, H. (Ed). Coast to Coast - Arrival. Results and reflections. Pp. 435-467. Coast to Coast Book 10. Uppsala.

Pettersson, M. \& Wikell, R. 2006a. Mesolitiska boplatser i Stockholms skärgård. Fiske och säljakt på utskären under 10000 år. Formvännen 101. Pp. 153-167. Stockholm.

Pettersson, M. \& Wikell, R. 2006b. Arkeologi. In: Pettersson, U. (Ed). Branden i Tyresta 1999: dokumentation av effekterna. Dokumentation av de svenska nationalparkerna nr 20. Pp. 134-155. Naturvårdsverket. Haninge.

Pettersson, M. \& Wikell, R. 2006c. Såg någon människa Närkesundet? På spaning efter pionjärer i Tiveden för 11000 år sedan. In: Holm, J. (Ed). Blick för Bergslagen. Årsbok 2006. Pp. 39-46. Riksantikvarieämbetet. UV Bergslagen. Örebro.

Risberg, J. 2003. Landscape history of the Södertörn peninsula, eastern Sweden. In: Larsson, L., Kindgren, H., Knutsson, K., Loeffler, D. \& Ákerlund, A. (Eds). Mesolithic on the Move: Papers Presented at the Sixth International Conference on the Mesolithic in Europe. Stockholm 2000. Pp. xlv-xlviii. Oxford: Oxbow Books.

Sørensen, M. 2003. Experiments with the "Tågerup pressure tool". In: Karsten, P. \& Knarrström, B. (Ed). The Tågerup Excavations. Skånska spår - arkeologi längs Västkustbanan. National Heritage Board, UV Syd. Pp. 146-149. Lund.

Schmitt, L. 2003. Points of interest and a point of view. In Situ. Västsvensk Arkeologisk Tidskrift 2003. Pp. 105-1 14. Göteborgs universitet. Göteborg.

Welinder, S. 1973. The Pre-Pottery Stone Age of Eastern Middle Sweden: Sjöweten-Hagtorp-Östra VräÖverrada. Antikvariskt Arkiv 48. Stockholm.

Welinder, S. 1977. The Mesolithic Stone Age of Eastern Middle Sweden. Antikvariskt arkiv 65. Kungliga Vitterhets Historie och Antikvitets Akademien. Stockholm.

Werthwein, G. 2000. Tillverkades mikroavslag med bipolär slagmetod? Fortsatt mikroteknologi under neolitikum? In: Ersgård, L. (Ed). Människors platser - tretton arkeologiska studier från UV. Riksantikvarieämbetet. Arkeologiska Undersökningar, Skrifter 31. Pp. 229-235. Göteborg.

Wikell, R. 2005. Actions in quartz. Some reflections on shiny white stones in eastern central Sweden. In: Gruber, G. (Ed). Identities in transition. Mesolithic strategies in the province of Östergötland. Riksantikvarieämbetet, Arkeologiska undersökningar, Skrifter 64. Pp. 88-99. Linköping.

\section{PERSONAL COMMUNICATION}

Kjel Knutsson, Uppsala University

Jenny Holm, National Heritage Board 